\title{
The Values of Character Education in the Didong Art Performance: A Study of Enculturation Process in Gayonese Society
}

\author{
Jona Erwenta; ${ }^{*}$ Leo Agung; Sunardi Sunardi \\ Department of History Education, Faculty of Teacher Training and Education, Sebelas Maret University, Indonesia \\ Email: jonaerwenta@gmail.com
}

http://dx.doi.org/10.18415/ijmmu.v5i4.248

\begin{abstract}
This research is promoting the values of Didong as a content supplement to elevating the practice of character education in the current curriculum of Indonesia. The main objective of this research is to describe explicitly the character values of Didong art. The qualitative with socio-historical approach was used as a research approach to finding historically and socially the existence of Didong art. The data were collected through literature review and field observation. The results of the research show that the Didong art came from Central Aceh District, particularly this art exists in the Gayo`s ethnic area. Didong art can be categorized as an indigenous art that consists of the combination of dance, vocal, and literature elements. In its beautiful performance, the Didong art contains character values that derive from the poetic verses of background song and dance motion. The character values of Didong art comprise of religious values, appreciate the achievement, communicative, peacefulness, and social care. These values could be inserted in the educational field, particularly in the practice of character education, in form of content enrichment. The character education is necessary to be developed because of the problem of moral degradation of the young generation. The implementation of character education, which contain the local values such as in the Didong art, would support the people`s personal and social life in the family, friendship, society, as well as in nationhood to achieve the better life in the future.
\end{abstract}

Keywords: Didong Art; Gayonese; Character Education;

\section{Introduction}

Indonesia is the nation that has rich natural as well as human resources. Unfortunately, the current problems in Indonesia have shown a discrepancy in which the richness of natural resources is not sustained by the development of human resources. At the same moment, the wave of globalization is inevitable and generates new kind of cultural and mentality problems in society, such as cultural lag and cultural shock, as a manifestation of the Huntington`s argumentation, a clash of civilization. Those simultaneously affect the personal character and the character of any society, particularly to the character of the young generation. These problems force the society to improve their personal maturity, thus, it makes the society realize that the quality improvement of human character, skills, and abilities are to be developed. 
Among that human personality, the character is one of the important aspects of humanity that should be fostered in the globalized age. Many societies have adopted a mechanism to foster their character. Generally, the society believes that education is a prominent element to foster the national character. The education, from the early age to the higher education, is set to develop the learner`s character by implementing a particular education system, policy, and learning material. Ideally, the character should be built in the early age, which is the critical period of human character building. The failure of character building in the early age would cause personality problems. The parent's role to educate their children, particularly in how the children solve the personality conflict in the early stage, prescribe the children`s social skills in the adult period.

Character education is perceived to becomes a solution to solve those personality problems. Character education refers to an educational approach that emphasizes the development of children`s personality, which is comprised of cognitive aspect, feeling aspect and action aspect. According to Lickona, the character education would not be effective without this three aspects of children's personality. Thus, the practice of character education should be implemented systematically and sustainable (Muslich., 2011: 29). In another definition, the character education could be defined similarly as values and moral education, which is realized and performed in real action. It consists of the values and attitude formation based on the existing knowledge. All those values and attitude helps the children to become a fully human. The good character is constructed by a good understanding, a good willing, and do a good thing in form of good habits such as in the ways of thinking, ways of feeling, and ways of acting. These three aspects are needed for the children to leads them to a moral life and moral building (Lickona., 2012: 82).

One of the fundamental resources to develop the human`s character is culture. Naturally, culture is one aspect of human life that contains character values. According to Ade Panjaitan et.al (2014: 20), in its relation to the expected character building, then both of culture and education is assistance each other. Culture is the idea system, habits, and human creations that exist and lives in the society, in which it is achieved by the process of enculturation (Koentjaraningrat., 2009:144). It means the cultural activities relate the human activity in creating meaning that refers to reality other than daily experience. Culture, which consists of cultural values, has a function to shape the human character. Thus, naturally, there are educational values inside of culture, which one of them is character education.

Koentjaraningrat (2009: 165) formulates seven elements of culture that can be found in others areas in the world. The seven elements are language, knowledge system, social organization, living system, living equipment, and technology, livelihood system, religious system, and art. From Koentjaraningrat's frameworks, art is categorized as the part of the culture. Art is the valuable assets owned by a nation, including Indonesia. The arts, which exist in Indonesia, is one thing that makes Indonesia known to the world. Almost in every region of Indonesia has distinctive art that represents the characteristics and a pride of the people.

Aceh is one of the provinces in Indonesia that has a distinctive art. Because of its geographical landscapes, Acehnese arts spread in some areas, one of them is in Central Aceh district. The district of Central Aceh located in the central region of Aceh Province. This district culturally has many arts, which one of them is Didong. Didong art belongs to the Gayo ethnic. Gayonese is the indigenous people in Central Aceh district. Didong art is considered has the same age as the Gayonese. For Gayonese, Didong art is not merely artistic. Many values can be derived from the arts, both if they become perpetrators or as a connoisseur. It is not surprising that in every Didong art performance, many people flock to participate as they did not want to pass every moment on the stage. Gayonese is a society that holds the religious values of Islam, in which in their daily life, the religious values are always upheld and accompanied by customs values. All aspects of Gayonese`s life are not separated from religious values, likewise, Didong art. 
This article will present the Didong art as a medium of character education, in which the values of character education in Didong art can be benefited for life, especially for Gayonese itself. According to these objectives, this article seeks to reveal the answers to the following the questions regarding the definition of character education, the definition of Didong art, and the elucidation of character values of Didong art.

\section{The Didong Art Performance}

According to Gayonese, Didong art develops in various versions from its emergence since nowadays. Some argue that this art developes as old as the existence of Gayonese. The literal and vocabulary meaning of the Didong is not very clear since nowadays. Probably, the Didong word could be understood by comparing this word with some other vocabulary in the Gayo language, such as denang or donang, whose the meaning is same as "dendang" or "musical rhyme" in the Indonesian language. However, Didong art has a broader sense meaning from just a "musical rhyme" (Melalatoa., 2001: 9).

According to Zulfikar or popularly known as Ama Zul Bayakku (Interview dated January 18., 2018), Didong art comes from the word "enti dong", which means do not stop. The words "enti dong" addressed to the White Elephant when it brought to the capital of Aceh Kingdom, Kutaraja, by Sengeda. At that time, Sengeda used an art of dance and literature equipped with several types of traditional art instruments to sing a song that contained words enti dong. This song was then followed by an entourage of the members of Linge Kingdom on the way escorting the White Elephant from Lingga Land to Kutaraja at the end coastal of Aceh. Meanwhile, Ara LK (2008: 131) stated that Didong art is the traditional art or oral tradition, which is a resemblance of sound art, literary arts, and dance art. Didong art comes from the Highland of Tanah Gayo in Central Aceh. Didong art is a contested art between two groups that representing a clan or a village, a subdistrict, even covertly representing a "paroh-society".

Pinan (2003: 185) stated another opinion that Didong art is a collected poem, which is classified as poetic. The Didong language revealed the surface of the various feelings that is in the hearts of the artists. It is called a sense of emotion, sadness, sorrow, joy, and in the form of protests, suggestions, satire, advice, and prohibitions. The resemblance of any element of art creates a beautiful appearance in Didong performance. Suryo, (2011: 8) stated that Didong art consists a number of art elements that are summarized, such as Kekitiken/Ure-ure, Kekeberen, Melengkan, and Sebuku.

Kekitiken is the art of the puzzle that is usually told to the children before bed. Language and sentence that used in this puzzle are concerned with sounds and rhythms with the pattern of a-b a-b. Kekeberen or oral prose is a traditional prose that delivered orally and gained in Gayo society in the past. Same as Didong art, this prose is usually spoken at night before bed. The narrator may be a grandmother or the elders who told the sing a story to their grandson. Among the themes are about love, obedience to parents, intellect, imitation and so forth. Melengkan is the art of customary speech in traditional events. Gayonese expressing their sense of art in form of poetic words. This customary speech is held by reciprocal actions in which the listener can be felt lost or won. Sebuku or the art of lamentation is the expression of feelings that exist in certain poems that are generally only done by women. The contents sebuku usually express the poetic sad verse.

Didong art commonly performs in a combination of sounds, literature, dances, and claps. The artist sits on a small pillow, with the width of $10 \mathrm{~cm}$ and length $15 \mathrm{~cm}$, and The Ceh or the leader of Didong art is singing a song on the typicality of the Gayonese song. Commonly, Didong art is played by 30 people, who sit around kneeling. The Didong art begins at night starts at $9 \mathrm{pm}$ until overnight or before the dawn. The performances appear within 30 minutes and alternate it covers contestation between 2 kelop didong. 
Didong is usually played at weddings ceremony or at meetings. Didong art is also performed in the form of a game as a medium of dakwah, silaturrahmi, and fundraising. Didong is played in a sitting cross-legged. Each song is always started by the Ceh, then followed simultaneously by others artists accompanied by a thunderous clap and applause. The performance of Didong art always features poems that belong to the literary arts. The Poems were sung by the Ceh always have values and certainly have a purpose. The words and verses in the Didong art are always nailed, whether orientalized with natural objects or celestial bodies. It means, in Didong art, every intent and purpose that is delivered in the performance is expressed indirectly or by way of bluntly. However, the Ceh have clarified Didong's poems, who then their oppose artist as well as the audience counterparts think about the meaning and interpret what the intent of Ceh's poem chants in his previous poetry.

Besides of the beautify, the Didong art comprises of values related to human life. One of them is about the values of education, which contains in the poem sing by the Ceh. In Didong art, the Ceh is not a haphazard person. The $\mathrm{Ceh}$ are the people who have extensive knowledge relating to matters of religion, customs, social, community, life, and the problems that are currently developing. The following discussion will be examined the art of Didong as a medium of dakwah and the unifying event of Gayo society. Before the further discussion, it is necessary to know what the definition of the character and the possibilities is to inserted the values of Didong art in the praxis of character education.

\section{The Definition of Character Education}

According to Kupperman (1991: 3), a word character terminologically comes from the ancient Greek language, which has a mean an instrument for marking and graving, impress, stamp, a distinctive mark, and distinctive nature. Berkowitz, which was cited by Damond (2002: 48), defined character as, "... an individual's set of psychological characteristics that affect person's ability and inclination to function morally. In Berkowitz`s definition, the characters are attributes or signs attached to an object or person, in which character can be used as a marker. The character, according to the observation of a contemporary philosopher named Michael Novak, is "a compatible mix of all the good that is identified by religious traditions, literary tales, wise men, and intelligent people in history" (Lickona., 2012: 81).

As the Novak shows, no one has all the good, and everyone has some weaknesses. The Novak's argumentation shows that the inconsistency of the character, in which the people who often had praised characters can be acted in different ways from his habitual action. Based on this understanding, there is a way of thinking about the proper character for values education, that is, the character consists of an operative value, the value in action. Someone proceeds in character, as a value becomes a virtue.

According to Nursalam Sirajuddin, who was cited by Asmani (2011: 26), the term of character was used in the education field specifically at the end of the $18^{\text {th }}$ century. The term was introduced by FW Foerster, as a terminology to refers an idealist-spiritualist approach to education or also known as the theory of normative education. According to Samani and Hariyanto (2013: 45), character education is the process of giving guidance to learners to be a fully human, who characterized in the dimensions of heart, mind, body. Meanwhile, others have argued that character education is an attempt to instill the intelligence of thought, appreciation in the form of attitude, and experience in the form of behaviors. Those attempts are in accordance with the noble values that seek their identity, manifested in interacting with God, self and among others and the environment (Johansyah., 2017: 46). Character education can be interpreted identically to the value education, character education, and moral education. Character education aims to develop the ability of learners to give good decisions, maintain good and realize that goodness in everyday life with a vengeance. By the character education, the children's character will develop the emotionally intelligent. The emotional intelligence is the most important provision in 
preparing children for the future challenges. The emotional intelligence supports the human maturity to the face of all kinds of challenges, including the challenge to succeed academically.

\section{The Objectives and Function of Character Education in Indonesia Curriculum}

The objective of education is to develop the potency of the learners. By the education, the learner can function, individually and collectively, as the member of the community. Through the implementation of education and teaching that is active, scientific and socializing and based on real life, can develop the soul, knowledge, responsibility, skills, a subtlety of character (Sukardjo and Komaruddin., 2009: 14). Others argue that character education aims to improve the quality of the implementation and outcomes of education. The quality improvement leads to the attainment of character formation and noble character of the learner intact, integrated and balanced, as per the competency standards of graduation (Sofan Amri et al., 2011: 31). Through character education students are expected to be able to independently improve and use their knowledge, review and internalize fiber personalize the values of character and noble character so that embodied in everyday behavior.

The relation between the purpose of cultural education and character of the nation can be described by some the goal of cultural education and character of the nation. The cultural and character education aims to develop the potency of affective aspect of the learners as a fully human and Indonesian citizen, who has cultural values and national characters. A further objective of culture and character education is to habituate the good behavior and attitudes in line with the traditional and universal religious values. Besides that, the education also has a role to impart the leadership and responsibilities of the students as the next generation. Another impact of culture and character education is developing the student's ability to become an independent, creative, and nationalized. The cultural and character education also develop the school environment as a learning environment that embarks the students, to be honest, full of creativity, and the high nationalism.

The function of cultural and character education covers some aspect of education, encompassing the development, recovery, and filtering functions. The function of development is to develop the potency of the learner to have a good personality that represents the culture and character of the nation. The function of recovery refers to an effort to strengthen the dynamic of national education, to be responsible for the development of potency of the learner. Meanwhile, the function of filtering refers to selecting process of relevant foreign culture according to the cultural and character values of a dignity nation (Center of Reseach and Development of Curriculum., 2010: 7).

The cultural and character education is necessary to be implemented to the learners. The values of culture and character education could be inserted in the learning syllabi and then developed into the lesson plan. The values, which are developed in the cultural and character education, could be identified as follow: religious values, honesty, toleration, discipline, hard work, creativity, independently, democratic, the willingness to know, spirit of nationality, love the homeland, praise the achievements, communicative, peacefully, love to read, environmental care, social care, and responsibility (Center of Reseach and Development of Curriculum., 2010: 9).

\section{The Character Values of Didong Art}

As the authors were described before, there are 18 values of character in the learning process. The Didong art also contains some values that identic with those 18 values. The values of Didong art are religious values, appreciate the achievement, 


\section{Religious Values}

Religious value is the core values of Didong art. It because the Didong art was born and developed in Central Aceh region, where the Islam is posited in a high position in the social and religious life of the society. The verses of Didong art commonly relate to the Islamic values, in which the spectator of this art, would likely, is hypnotized by the spiritual atmospheres because the verses are identic with the content of Islam in Dakwah. The difference between the Didong art and Dakwah is in how it is expressed in form art performance of a musical rhyme and song.

\section{Appreciate the Achievement}

Inside of the Didong art, particularly in the Didong Jalu art performance that contested 2 kelop, is always look attracting in the eyes of the spectators. It because the function of Didong art is to attract the society, thus, the appearance of the artist should be appealed. The Ceh, who is the main actor in the art performance, always creates new verses to defeat their opposites. The Ceh s verses, not often, contain the limerick or satire materials. This makes the opposite kelop should listen carefully and then reply the Ceh's verses. In this contestation, the kelop should appreciate the works or achievements of their counterparts. The mutual appreciation of achievement among fellow artists of Didong art has been running as a tradition. It proves that Didong art contains values of achievement.

\section{Communicative}

The performance of Didong art is always contested by two kelop. The kelops are coming from different villages, and often the villages come from different sub-districts. The number of Didong`s supporters among the Gayonese made them often watch Didong art wherever the performances were held. In this case, of course, the supporters came from any direction, especially the people from the districts which are represented by Didong's shovel or from the villages from each sub-district. In this case, Didong art serves as a silaturrahmi arena for those who witnessed the performances of the arts. So that the values of friendship and silaturrahmi will be intertwined at that moment.

\section{Peacefulness}

Peacefulness is one of the values in Didong art. The vast majority of the Ceh produce verses that contain the values of peace. This is not surprising because the district of Central Aceh is one of the areas where prolonged conflict from the post-independence war, Darul Islam/Islamic-Indonesia Army, and the emergence of the Free Aceh Movement have become part of the life of the people. The district of Central Aceh, which topographically is mountains and forests, was infrequently become the base camp of the combatants to seek protection. Prolonged conflict has made people always looking for peacefulness. The Ceh Didong, who has a high artistic spirit, pours their feelings in the form of poetry, which is then sung with hand clapping in the form of Didong art. One of most famous Ceh's poetry themes is Daman. His poetry is so phenomenal until now continues to be sung by anyone good in the performance of Didong Art, music art, poetry and so forth.

\section{Social Care}

Didong art is often played for social events. In the area of Central Aceh Regency, the early days of development independence in many ways it often stalled. Many infrastructures, from the mosques, 
roads, bridges, toilets are the main concerns to wake up. Another problem is concerning the victims of the disaster that unresolved until this day. Unfortunately, the economic power of the Government, which has not been as glorious nowadays especially in the field of funding, force the community to get others solutions to build public facilities. Didong art, as a popular art, present as an answer to the demand of public at the time. In short, the Gayonese agreed to play Didong art performance that involves two kelop. The performance was held overnight and was done by a ticket payment system for the spectators who want to see the game directly. At the end of the performance, the fund was collected and then submitted to the authorized party to carry out the construction of these facilities.

The values show that the Didong art is the part of enculturation process in Gayonese society. As other art and tradition, the Didong art transmits the religious values, appreciate the achievement, communicative, peacefulness, and social care over the generation. These values construct personal and social dimension of the people that affect in how the people characterizing their personal as well as social life.

\section{Conclusion}

Didong art is the popular art performance that exists in the Gayonese community. Gayonese believe that as long as the existence of Gayonese community, then Didong art will continue to show its existence as an art that its existence not only as a medium of entertainment but more than that as a device of enculturation. The values of Didong art will continue to be an attraction and provide broad benefits to the community. One of the values contained in Didong's art is the values of character education. There are five values of character education in Didong art. The values of the characters contained in the art Didong make this art is very worthy of serving as a medium of character education, especially for the younger generation of Gayonese who inhabit the district of Central Aceh and surrounding areas, particularly in the current era when moral depravity begins to undermine the younger generations of this Nation.

\section{References}

Ade Putra Panjaitan, Alan Darmawan, Maharani, Ikhwan Rivai Purba, Yopi Rachmad dan Ridayani Simanjuntak. (2014). Korelasi Kebudayaan \& Pendidikan Membangun Pendidikan Berbasis Budaya Lokal. Jakarta: Yayasan Pustaka Obor Indonesia.

Amri sofan, Ahmad Jauhari dan Tatik Elisah. (2011). Implementasi Pendidikan Karakter. Jakarta: PT Prestasi Pustaka.

Ara, L.K. (2008). Ensiklopedi Aceh Adat, Hikayat dan Sastra. Banda Aceh: Yayasan Mata Air Jernih (YMAJ).

Asmani, Jamal Ma'mur. (2011). Buku Panduan Internalisasi Pendidikan Karkter di Sekolah. Jogjakarta: DIVA Press.

Badan penelitian dan Pengembangan Pusat Kurikulum. (2010). Pengembangan Pendidikan Budaya Dan Karakter Bangsa. Jakarta. Kementerian Pendidikan Nasional.

Damond, William. (2002). Bringing New Era in Character Education. Standford Hoover Institution Press

Johansyah. (2017). Pendidikan Karakter Melahirkan Generasi Cerdas, Terampil, dan Berakhak. Tangerang: Mahara Publishing. 
Koentjaraningrat. (2009). Pengantar Ilmu Antropologi. Jakarta: Rineka Cipta.

Kupperman, Joel. (1991) Character. New York: Oxford University Press.

Lickona, Thomas. (2012). Educating for Character: How Our Schools Can Teach Respect and Responsibility. Jakarta: PT Bumi Aksara.

M. Sukardjo \& Komaruddin, Ukim. (2009). Landasan Pendidikan. Jakarta: PT Raja Grafindo Persada.

Melalatoa, M.J. (2001). Didong Pentas Kreativitas Gayo. Jakarta: Yayasan Obor Indonesia.

Muslich, Masnur. (2011). Pendidikan Karakter Menjawab Tantangan Krisis Multidimensional. Jakarta: PT Bumi Aksara.

Pinan, Aman, AR Hakim. (2003). Pesona Tanoh Gayo. Aceh Tengah: Pemerintah Kabupaten Aceh Tengah.

Setyantoro, Agung Suryo. (2012). Nelayan Depik Di Dataran Tinggi Gayo. Banda Aceh: Balai Pelestarian Sejarah dan Nilai Tradisional (BPSNT).

\section{Copyrights}

Copyright for this article is retained by the author(s), with first publication rights granted to the journal.

This is an open-access article distributed under the terms and conditions of the Creative Commons Attribution license (http://creativecommons.org/licenses/by/4.0/). 